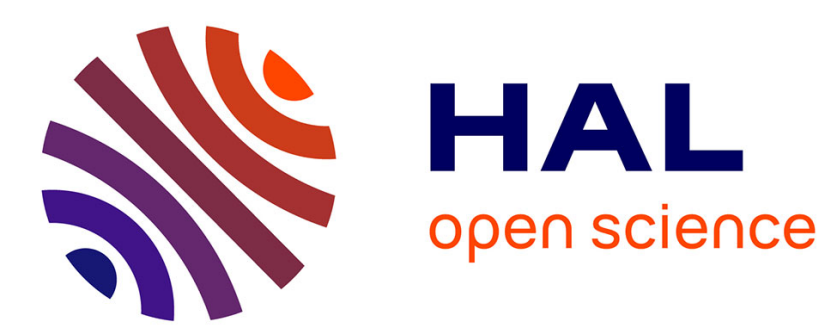

\title{
Characterizing the Uncertainty of the Fundamental Matrix
}

\author{
Olivier Faugeras, Zhengyou Zhang, Cyril Zeller, Gabriella Csurka
}

\section{To cite this version:}

Olivier Faugeras, Zhengyou Zhang, Cyril Zeller, Gabriella Csurka. Characterizing the Uncertainty of the Fundamental Matrix. RR-2560, INRIA. 1995. inria-00074121

\section{HAL Id: inria-00074121 https://hal.inria.fr/inria-00074121}

Submitted on 24 May 2006

HAL is a multi-disciplinary open access archive for the deposit and dissemination of scientific research documents, whether they are published or not. The documents may come from teaching and research institutions in France or abroad, or from public or private research centers.
L'archive ouverte pluridisciplinaire HAL, est destinée au dépôt et à la diffusion de documents scientifiques de niveau recherche, publiés ou non, émanant des établissements d'enseignement et de recherche français ou étrangers, des laboratoires publics ou privés. 
INSTITUT NATIONAL DE RECHERCHE EN INFORMATIQUE ET EN AUTOMATIQUE

\section{Characterizing the Uncertainty of the Fundamental Matrix}

Gabriella CSURKA

Cyril ZELLER

Zhengyou ZHANG

Olivier FAUGERAS

$\mathbf{N}^{\circ} 2560$

Juin 1995

PROGRAMME 4 



\title{
Characterizing the Uncertainty of the Fundamental Matrix
}

\author{
Gabriella CSURKA \\ Cyril ZELLER \\ Zhengyou ZHANG \\ Olivier FAUGERAS \\ Programme 4 - Robotique, image et vision \\ Projet Robotvis \\ Rapport de recherche $\mathrm{n}^{\circ} 2560-$ Juin $1995-29$ pages
}

\begin{abstract}
This paper deals with the analysis of the uncertainty of the fundamental matrix. The basic idea is to compute the fundamental matrix and its uncertainty in the same time. We shall show two different methods.

The first one is a statistical approach. As in all statistical methods the precision of the results depends on the number of analyzed samples. This means that we can always improve our results if we increase the number of samples but this process is very time consuming.

We propose a much simpler method which gives results which are close to the results of the statistical methods.

At the end of paper we shall show some experimental results obtained with synthetic and real data.
\end{abstract}

Key-words: Epipolar geometry, Fundamental matrix, Uncertainty, Covariance matrix

(Résumé : tsvp)

Unité de recherche INRIA Sophia-Antipolis

2004 route des Lucioles, BP 93, 06902 SOPHIA-ANTIPOLIS Cedex (France)

Téléphone : (33) 93657777 - Télécopie : (33) 93657765 


\section{Caractérisation de l'incertitude de la matrice fondamentale}

Résumé : Ce papier propose une analyse de l'incertitude liée à la matrice fondamentale. L'idée de base est de calculer la matrice fondamentale et son incertitude en même temps. Nous montrons deux méthodes différentes.

La première est une méthode statistique. Elle ne donne donc de résultats précis qu'au prix de l'analyse d'un grand nombre de réalisations, ce qui en fait une méthode coûteuse en temps.

La seconde est une méthode analytique. Elle est trés peu coûteuse en temps mais approximative. Nous montrons dans ce papier, à partir d'images synthétiques comme d'images réelles, qu'elle donne cependant des résultats suffisamment proches de ceux de la méthode statistique pour être utilisée dans la pratique.

Mots-clé : Géométrie épipolaire, Matrice fondamentale, Incertitude, Matrice de covariance 


\section{Contents}

1 Introduction $\quad 2$

2 The fundamental matrix 2

3 Computing the fundamental matrix 3

3.1 The linear criterion . . . . . . . . . . . . . . . . . 4

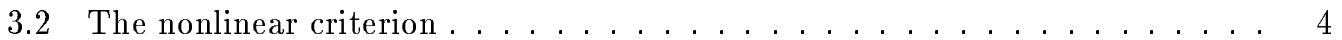

3.2.1 A parameterization of the fundamental matrix . . . . . . . . . . 4

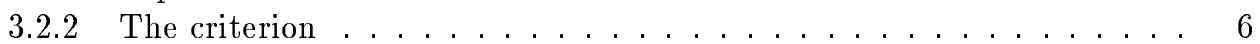

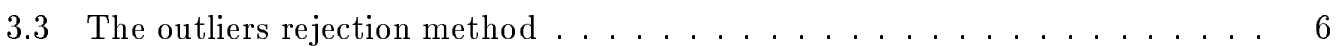

4 The covariance matrix 6

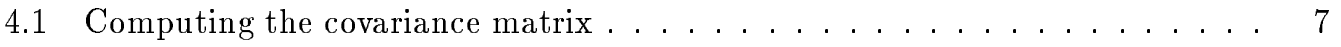

4.1.1 The statistical method . . . . . . . . . . . . . . 7

4.1 .2 The analytical method . . . . . . . . . . . . . 7

4.2 The hyper-ellipsoid of uncertainty $\ldots \ldots \ldots \ldots$

5 Experimentation $\quad \mathbf{1 0}$

5.1 Notations . . . . . . . . . . . . . . . . . . . . . . 11

5.2 Synthetic data . . . . . . . . . . . . . . . . . . 12

5.2 .1 Statistical Method . . . . . . . . . . . . . . . . . . 14

5.2 .2 Analytical Method . . . . . . . . . . . . . . . . . . . 19

5.2 .3 Real data . . . . . . . . . . . . . . . . . . . . 24

6 Conclusion $\quad 28$

$\mathrm{RR} \mathbf{n}^{\circ} 2560$ 


\section{Introduction}

The study of the fundamental matrix is very recent in computer vision. It was introduced in [FLM92] as a generalisation of the essential matrix described in [LH81] to uncalibrated images. The importance of the fundamental matrix becomes evident in the case of two the uncalibrated cameras. In this case the fundamental matrix is the key concept, as it contains all the geometrical information relating two different images. It determines and is determined by the positions of the two epipoles and the epipolar transformation mapping an epipolar line of the first image to its corresponding epipolar line in the second image. It can be computed from a certain number of point correspondences obtained from the pair of images using some correlation based algorithms, independently of any other knowledge about the world.

In the first part of this paper we describe some methods to compute the fundamental matrix from a pair of images assuming that some image point correspondences are known. The methods are not detailed more than necessary because they have been already presented in the literature ([Luo92, HGC92, Ols92, Har95]).

In the second part two different methods are presented to compute the covariance matrix of the fundamental matrix. The stability of the fundamental matrix has already been studied by Q.-T.Luong ([Luo92], [LF94]), but the corresponding covariance matrix was not accurately estimated, in particular the variances were too much overestimated to be used in further computations.

We shall show in the last part of this report that using the two methods we propose we obtain a much better estimation of the uncertainty of the fundamental matrix.

\section{The fundamental matrix}

The camera model used is the classical pinhole model. If the object space is considered to be the 3 -dimensional Euclidean space $\mathcal{R}^{3}$ embedded in the usual way in the 3 -dimensional projective space $\mathcal{P}^{3}$ and the image space the 2-dimensional Euclidean space $\mathcal{R}^{2}$ embedded in the usual way in the 2-dimensional projective space $\mathcal{P}^{2}$, the camera is then described as a linear projective application from $\mathcal{P}^{3}$ to $\mathcal{P}^{2}$ (see [Fau93]). If we denote by $\tilde{\mathbf{P}}$ the $3 \times 4$-matrix representing this application, we have:

$$
\lambda \mathbf{m}=\underbrace{\left[\begin{array}{ll}
\mathbf{P} & \mathbf{p}
\end{array}\right]}_{\tilde{\mathbf{P}}} \mathbf{M}
$$

where $\mathbf{p}$ denotes the last column of $\tilde{\mathbf{P}}, \mathbf{M}=[X, Y, Z, 1]^{T}$ represents an object point $M, \mathbf{m}=$ $[x, y, 1]^{T}$, its projection $m$ onto the image and $\lambda$ a nonzero scalar. We assume $\operatorname{rank}(\mathbf{P})=3$.

If we have two cameras, represented by $\tilde{\mathbf{P}}$ and $\tilde{\mathbf{P}}^{\prime}$, by eliminating $\mathbf{M}$ from equation (1), we obtain the relation between the projections of $M$ onto the first and second image:

$$
\lambda^{\prime} \mathbf{m}^{\prime}=\lambda \mathbf{H m}+\mathbf{e}^{\prime}
$$

